\begin{tabular}{|c|c|c|c|}
\hline KULTURA & \multicolumn{2}{|c|}{$\begin{array}{l}\text { POLSKA AKADEMIA NAUK } \\
\text { KOMITET SOCJOLOGII } \\
\text { INSTYTUT STUDIÓW POLITYCZNYCH }\end{array}$} & ISSN 0023-5172 \\
\hline SPOLECLESTMO & 2016 , nr 3 & TRUDNE RELACJE & \\
\hline
\end{tabular}

IZABELA ŚLĘZAK

Uniwersytet Łódzki

\title{
REALIZACJA POTRZEB SEKSUALNYCH \\ PRZEZ OSOBY NIEPEŁNOSPRAWNE: \\ RZECZYWISTOŚĆ — PERSPEKTYWY - KONTROWERSJE
}

O potrzebach seksualnych osób niepełnosprawnych przez wiele stuleci milczano (Lew-Starowicz 1999). W kontekście codziennych wyzwań stających przed osobami niepełnosprawnymi fizycznie, ruchowo, sensorycznie temat ten uznawano za nieważny, błahy lub też (zwłaszcza w przypadku niepełnosprawnych intelektualnie) stanowiący trudny do rozwiązania problem (Kijak 2009, s. 43). Obecnie postrzeganie seksualności osób niepełnosprawnych i ich prawa do realizacji swoich potrzeb się zmienia. Dzieje się tak między innymi z powodu powszechniejszej obecności tych zagadnień w dyskursie publicznym. Coraz częściej też skupiają one uwagę badaczy z różnych dyscyplin naukowych. Poświęcane są im konferencje i publikacje naukowe, teksty popularnonaukowe, sięga po nie również popkultura, ukazując szerszemu odbiorcy to, co do niedawna stanowiło tabu. Zmiany zachodzą także na gruncie prawa, czego przykładem może być Konwencja Praw Osób Niepełnosprawnych uchwalona przez ONZ w 2006 roku, a ratyfikowana przez Polskę 6 września 2012 r. Jej zapisy mają na celu między innymi wyeliminowanie dyskryminacji osób niepełnosprawnych w sferach małżeństwa i rodzicielstwa (Żyta 2013). Jednakże wspomniane działania znacznie wyprzedzają powolne zmiany zachodzące w społecznym postrzeganiu tej kwestii. Jak wskazuje wielu badaczy, tak jak niepełnosprawne ciało „wypada z ekonomii pożądania” (Iwasiów 2002, s. 292), tak seksualność osób $z$ dysfunkcjami w dużej mierze ciągle jest seksualnością społecznie niechcianą (Kościelska 2004, s. 28). Ponieważ sfera potrzeb seksualnych i sposobów ich zaspokajania jest niezmiernie podatna na kształtujące je oddziaływania kultury i uwarunkowań społecznych, podlega silnym re- 
gulacjom normatywnym, moralnym, religijnym i prawnym (Fairbairn, Rowley 2005; Ostrowska 2007, s. 11). Oddziaływania te, krzyżujące się z ograniczonymi możliwościami realizacji ról społecznych związanych ze sferą seksualności, mają dojmujące konsekwencje dla życia osób niepełnosprawnych.

Wszystko to sprawia, że znajdujemy się obecnie w interesującym momencie - $z$ jednej strony rośnie wiedza na temat seksualności osób niepełnosprawnych i (przynajmniej deklaratywna) akceptacja dla realizacji potrzeb $\mathrm{w}$ tym zakresie $^{1}, \mathrm{z}$ drugiej zmiany te jedynie $\mathrm{w}$ niewielkim stopniu (o ile $\mathrm{w}$ ogóle) przekładają się na życie codzienne wielu osób (zwłaszcza niepełnosprawnych intelektualnie). Jednocześnie obok „standardowych” (wpisanych w kulturowo utrwalony obraz osoby niepełnosprawnej) sposobów „radzenia sobie” z seksualnością, co pewien czas media prezentują „kontrowersyjne” drogi, mające otwierać przed osobami niepełnosprawnymi szersze możliwości realizacji ich pragnień. Są to terapia i asystentura seksualna oraz prostytucja. Ich odbiór, zarówno przez społeczeństwo, naukowców, praktyków, jak i osoby niepełnosprawne, jest niezwykle zróżnicowany — od nadziei i przekonania, że dzięki nim osoby niepełnosprawne będą miały szansę na realizację swoich potrzeb, po oburzenie i obawy o skutki ewentualnego korzystania $z$ takich usług.

Dlatego warto poddać głębszej analizie społeczne postrzeganie seksualności osób niepełnosprawnych oraz faktyczne możliwości realizacji przez nie potrzeb seksualnych. Kluczowe znacznie dla tych kwestii ma perspektywa przedstawicieli nauk społecznych i humanistycznych, profesjonalistów na co dzień pracujących $z$ osobami niepełnosprawnymi w czasie rehabilitacji i terapii, a także członków ich rodzin. Sposób, w jaki rozumieją oni seksualność osób niepełnosprawnych, wpływa na to, jak osoby te definiują swoje potrzeby oraz jakie mają możliwości ich realizacji. Niezbędnej wiedzy w tym zakresie mogą dostarczyć wyniki badań dotyczących realizacji potrzeb seksualnych przez niepełnosprawnych ruchowo i intelektualnie. Obraz ten należy uzupełnić o aspekt komercyjny usług seksualnych. Odwołując się do literatury przedmiotu zaprezentuję zagadnienie terapii seksualnej z partnerem zastępczym oraz asystentury seksualnej. Na podstawie badań własnych przedstawię natomiast perspektywę kobiet świadczących usługi seksualne, które przyjmowały niepełnosprawnych klientów. Zestawienie ze sobą perspektyw naukowych i potocznych, wzorów akceptowanych i nieakceptowanych społecznie sposobów zaspokajania potrzeb

${ }^{1}$ Badania Zbigniewa Izdebskiego (na reprezentatywnej próbie 1004 Polaków powyżej 15 roku życia) wskazują, że w opinii respondentów życie seksualne odgrywa taką samą rolę w życiu osób pełno- i niepełnosprawnych, choć poziom akceptacji tego stwierdzenia był różny w zależności od rodzaju niepełnosprawności. Opinię tę podzielało $69 \%$ respondentów w odniesieniu do osób niepełnosprawnych ruchowo i 54\% do niepełnosprawnych intelektualnie (Izdebski 2005, s. 35). 74\% respondentów w pełni akceptowało i uważało za zdecydowanie właściwe, by osoby niepełnosprawne ruchowo darzące się uczuciem prowadziły życie intymne i rodzinne takie jak osoby pełnosprawne (Izdebski 2005, s. 45). Podobną opinię w stosunku do osób niepełnosprawnych intelektualnie podzielało 39\% respondentów (Izdebski 2005, s. 47). 
seksualnych przez osoby niepełnosprawne pozwala odpowiedzieć na pytanie, $\mathrm{w}$ jakim stopniu przyznawane im $\mathrm{w}$ tym zakresie prawa są realizowane $\mathrm{w}$ praktyce.

\section{POTRZEBY SEKSUALNE OSÓB NIEPEŁNOSPRAWNYCH W PERSPEKTYWIE NAUKOWEJ}

Współczesne naukowe podejście do seksualności osób niepełnosprawnych (przede wszystkim osób niepełnosprawnych intelektualnie) jest efektem procesu dekonstrukcji aksjomatów wcześniej uznawanych za oczywiste, następnie zaś podważonych. Dominujący do niedawna medyczno-opiekuńczy model niepełnosprawności, który przyczynił się do wykluczenia jej z przestrzeni społecznej, odpowiedzialny jest także za perspektywę postrzegania potrzeb seksualnych tej grupy jako tabu oraz problemu do rozwiązania. Zwłaszcza w przypadku niepełnosprawności intelektualnej oczekiwano, że medycyna pomoże uporać się z zachowaniami seksualnymi (np. masturbacją) definiowanymi jako patologiczne. Podstawowym zadaniem opiekunów osób niepełnosprawnych było więc tłumienie potrzeb seksualnych podopiecznych oraz przeciwdziałanie ich aktywności seksualnej (Kijak 2009, s. 33). Takiemu podejściu sprzyjały (w znacznej mierze podzielane także obecnie) mity i stereotypy dotyczące seksualności tej grupy osób niepełnosprawnych. Jednym z najbardziej rozpowszechnionych jest postrzeganie ich jako dzieci, które nie maja potrzeb przynależących do świata dorosłych, a tym samym nie interesuje ich seksualna sfera życia. Konsekwencją takiego podejścia jest brak dla tej grupy osób odpowiednio przygotowanej edukacji seksualnej (Kijak 2009, s. 13), którą postrzega się jako niepotrzebne „pobudzanie” ich seksualności (Pilecka 2004). Jednocześnie równie rozpowszechniony jest mit hiperseksualności (Karwacka 2006), który służy uzasadnieniu sprawowania kontroli nad niepełnosprawnymi intelektualnie i podejmowaniu działań wygaszających ewentualne przejawy ich aktywności seksualnej. Z kolei podzielane przez wiele osób przekonanie o dziedziczeniu niepełnosprawności jest argumentem przeciw akceptacji współżycia i prokreacji osób niepełnosprawnych intelektualnie (Pilecka 2004).

Inną perspektywę przyjmuje się w modelu społecznym, który zakłada, że seksualność jest wytworem społecznym, istniejącym w relacji z drugim człowiekiem. Na jego gruncie uznaje się, że osoba niepełnosprawna ma takie same prawa seksualne jak ludzie pełnosprawni, a więc ma prawo do wolności, odrębności i prywatności seksualnej, równości i przyjemności seksualnej, emocjonalnego wyrażania seksualności, swobodnych kontaktów seksualnych, podejmowania wolnych i odpowiedzialnych decyzji dotyczących potomstwa, informacji seksualnej opartej na badaniach naukowych oraz wyczerpującej edukacji seksualnej (por. Lew-Starowicz, Długołęcka 2006, s. 266-267). Tym samym podzielający tę perspektywę naukowcy zajmują stanowisko, że niezależnie od stopnia niepełnosprawności danej osoby odczuwa ona potrzeby seksualne, któ- 
re $\mathrm{w}$ toku jej życia pojawiają się i rozwijają. $\mathrm{Z}$ tego względu nie powinno się deprecjonować roli, jaką w jej życiu odgrywa miłość i budowanie relacji z płcią przeciwną. Należy raczej skoncentrować się na odpowiedzi na pytanie, jak najpełniej wspomagać osoby niepełnosprawne w optymalnym rozwijaniu potrzeb seksualnych (Kijak 2009, s. 12). Jak zauważa Antonina Ostrowska, w przypadku wielu osób niepełnosprawnych satysfakcjonujące życie intymne może mieć więcej pozytywnych konsekwencji niż dla ogółu osób aktywnych seksualnie. W tym kontekście szczególnego znaczenia nabiera nie tylko bycie spełnionym w związku, ale będące jego pochodną poczucie, że jest się akceptowanym (a tak$\dot{z}$ e, że akceptowane jest nasze ciało). Pozytywna samoocena, która wiąże się $z$ udanym życiem seksualnym, może przekładać się na szybsze przystosowanie się do codziennego życia z niepełnosprawnością i twórcze funkcjonowanie w różnych rolach społecznych. Jednakże satysfakcjonujące życie intymne osób niepełnosprawnych powinno być postrzegane nie tylko z perspektywy korzyści dla przebiegu rehabilitacji społecznej, ale jako niezbywalne prawo do ekspresji własnych potrzeb seksualnych. Osoby niepełnosprawne mają prawo same decydować o kształcie własnego życia intymnego, a jeśli tego chca, spełniać się seksualnie dla cielesnej rozkoszy i satysfakcji, jaką mogą czerpać z seksu (Ostrowska 2007, s. 13-14).

W tym miejscu można zadać pytanie - czy niepełnosprawność wpływa na sferę seksualną? Ogólnie można powiedzieć, że rozwój seksualny osób niepełnosprawnych przebiega w podobny sposób jak pełnosprawnych, ale niepełnosprawność może zmieniać odbierane bodźce seksualne (w przypadku osób niepełnosprawnych wzrokowo, słuchowo), wpływać na hormony płciowe i rozumienie potrzeb seksualnych (u osób niepełnosprawnych intelektualnie), wywoływać reakcje seksualne przez pobudzanie innych obszarów niż genitalne (po urazach rdzenia kręgowego) (Kijak 2013a, s. 15). Problemy osób z różnymi niepełnosprawnościami znacząco się od siebie różnią. Poniżej zarysuję tę problematykę $\mathrm{w}$ odniesieniu do dwóch (także wewnętrznie silnie zróżnicowanych) kategorii: osób niepełnosprawnych ruchowo i intelektualnie.

\section{POTRZEBY SEKSUALNE OSÓB NIEPEŁNOSPRAWNYCH FIZYCZNIE I RUCHOWO}

Wyniki badań dotyczących realizacji potrzeb seksualnych przez osoby niepełnosprawne ruchowo pokazują niejednorodny obraz tego zagadnienia. Z jednej strony wiele $z$ nich prowadzi satysfakcjonujące życie seksualne. Wskazują na to wyniki badań przeprowadzonych pod kierunkiem Zbigniewa Izdebskiego na próbie 800 osób ograniczonych ruchowo ze względu na urazy i schorzenia (m.in. uraz rdzenia kręgowego, stwardnienie rozsiane, porażenie mózgowe). Zgodnie z wynikami badań, 25\% respondentów jest bardzo zadowolonych ze swojego życia seksualnego, a $38 \%$ ocenia je jako „dobre”. Co drugi ankietowany deklarował, że partner/ka całkowicie akceptuje jego niepełnosprawność" 
(Filc Redlińska 2010). Z drugiej strony wiele wyników badań wskazuje, że osoby niepełnosprawne (zwłaszcza kobiety) częściej nie posiadają rodzin, rzadziej mają partnerów, a jeszcze rzadziej potomstwo (Ostrowska 2000). Z badań przeprowadzonych przez Hannę Żuraw na próbie 300 osób z dysfunkcjami sensorycznymi i motorycznymi wynika, że niemal $56 \%$ z nich nie miało partnera. Jako powód takiego stanu rzeczy respondenci podawali: lęk przed związaniem się z nieodpowiednią osobą, wpływ rodziny, która od najmłodszych lat utrwalała wyobrażenie o sobie jako kimś „nie nadającym się” do ról małżeńskich i rodzicielskich; przekonanie o swojej nieatrakcyjności; rozwód lub porzucenie przez partnera. Znaczący w tym względzie jest zwłaszcza wpływ najbliższego otoczenia społecznego, które zwykle niedowierza, że osoby niepełnosprawne (przede wszystkim kobiety) mogą sprostać wymaganiom znormalizowanej egzystencji i wypełniać tradycyjnie rozumiane role społeczne (żon i matek). W rezultacie podejmowane są wobec nich działania zniechęcające do myślenia o sobie w kontekście poszukiwania partnera i założenia rodziny (Żuraw 2013, s. 56-58). U podstaw tych przekonań może leżeć chęć ochrony osoby niepełnosprawnej przed rozczarowaniami i nietrafnymi decyzjami, jednak w konsekwencji często zostaje ona sama. Problemy ze znalezieniem partnera wiążą się także $z$ rodzajem dysfunkcji, która wpływa na poziom niezależności funkcjonalnej określany przez samodzielność poruszania się i komunikowania. Ogólnie rzecz biorąc, partnerów znajdują osoby poruszające się samodzielnie i dysponujące kompetencjami komunikacyjnymi (Żuraw 2013, s. 61).

Podobny obraz wyłania się z badań Dariusza Radomskiego (2004, s. 145-147), przeprowadzonych w grupie 69 osób z niepełnosprawnością ruchową w wieku 15-49 lat - 90\% respondentów w czasie badania pozostawało w stanie wolnym, $89 \%$ nie miało dzieci, a $56 \%$ nie miało partnera ( $27 \%$ badanych nigdy nie było w związku partnerskim). W badanej grupie niespełna $57 \%$ osób miało za sobą inicjację seksualną, którą przeżyły później niż ich pełnosprawni rówieśnicy. Wśród osób, które współżyły seksualnie, głównymi problemami były: trudności osiągnięcia odpowiedniej pozycji $(6,4 \%)$, zaburzenia erekcji $(4,8 \%)$ oraz bolesność narządów płciowych $(1,6 \%)$. Deklaracje te są zbieżne $z$ wynikami badań seksuologów, zgodnie z którymi głównymi problemami seksualnymi osób niepełnosprawnych fizycznie i ruchowo są: zanik popędu płciowego, brak pobudzenia i działania, ból i uczucie dyskomfortu podczas stosunku oraz brak orgazmu (Aouil 2010, s. 6). Wśród problemów zgłaszanych przez osoby niepełnosprawne ruchowo są także: poczucie bycia nieatrakcyjnym, gorszym; odczuwane uzależnienie od innych osób, które ingerują w relacje intymne i naruszają sferę intymności; problemy odczuwane $\mathrm{w}$ relacji z partnerem, związane z trudami przystosowania się do nowej sytuacji i koniecznością wypracowania nowych technik współżycia (Długołęcka, Fornalik 2013, s. 177). Problemy te stanowią obszar działania rehabilitacji seksualnej, dzięki której osoby niepełnosprawne mogą wypracować skuteczne mechanizmy realizacji potrzeb seksualnych, $z$ wykorzystaniem różnorodnych metod i przy uwzględ- 
nieniu indywidualnej sytuacji każdego niepełnosprawnego (Aouil 2010, s. 3). Można jednak zauważyć, że istnieje pewien rozdźwięk w ocenie rehabilitacji seksualnej. Z jednej strony holistyczny model rehabilitacji powinien uwzględniać rehabilitację seksualną (Adamczyk, Kocyk, Boguszewski 2012, s. 22). Jednakże osoby korzystające $z$ rehabilitacji rzadko $w$ jej trakcie spotykają się $z$ informacjami dotyczącymi zakresu ich możliwości seksualnych. Badanie Jakuba Adamczyka i współpracowników wykazało, że $86 \%$ respondentów (57 osób niepełnosprawnych $z$ uszkodzeniem narządu ruchu) nie miało dostępu do takich informacji, a zdaniem nielicznych, którzy mieli kontakt $z$ rehabilitacją seksualną, przekazywane treści nie były wystarczające. Co warto zaznaczyć, aż 70\% ankietowanych nigdy nie spotkało się z terminem „rehabilitacja seksualna” (Adamczyk, Kocyk, Boguszewski 2012, s. 25-26). Nierealizowanie w praktyce idei rehabilitacji seksualnej jest związane $z$ tym, że problematyka zaburzeń seksualnych to temat bardzo intymny i trudny przede wszystkim dla pacjenta, ale również dla lekarzy i terapeutów. Sytuacji nie poprawia brak odpowiedniego programu nauczania na uczelniach wyższych oraz niedostateczna liczba przedsięwzięć edukacyjnych w zakresie rehabilitacji seksualnej (Adamczyk, Kocyk, Boguszewski 2012, s. 24). Tymczasem zarówno osoby niepełnosprawne, jak i pracujący $z$ nimi specjaliści dostrzegają potrzebę pogłębienia wiedzy $\mathrm{w}$ tym zakresie. Interesujących wniosków w tym względzie dostarcza referowane badanie dotyczące oczekiwań wobec rehabilitacji seksualnej, przeprowadzone na próbie 66 osób niepełnosprawnych z uszkodzeniem narządu ruchu oraz 100 fizjoterapeutów. Najczęściej wskazywane przez respondentów potrzeby dotyczyły: przełamywania mitów, lęków i stereotypów (odpowiedź tę wybrało $74 \%$ fizjoterapeutów oraz $70 \%$ osób niepełnosprawnych), indywidualnego dostosowywania odpowiednich pozycji seksualnych (odpowiednio 89\% oraz 59\%), otrzymania informacji o przeciwwskazaniach do podjęcia współżycia (odpowiednio $85 \%$ oraz $50 \%$ badanych) oraz o budowaniu poprawnych relacji partnerskich (57\% i 42\%). Nieco rzadziej wymieniano potrzebę zdobycia informacji dotyczących możliwości stosowania akcesoriów seksualnych (odpowiednio $34 \%$ i $39 \%$ ) oraz nauki stref erogennych (31\% oraz 36\%) (Adamczyk, Kocyk, Boguszewski 2012, s. 24).

Wobec niedostatecznego objęcia osób niepełnosprawnych rehabilitacją seksualną mało rozpowszechniona jest także wiedza na temat stosowanych w niej metod treningowych. Można wśród nich wymienić między innymi, w zależności od wskazań medycznych oraz predyspozycji pacjentów i ich sytuacji rodzinnej, a także specyfiki dysfunkcji: ustalenia szkoły Mastersa-Johnson; trening świadomości seksualnej, treningi relaksacyjne; desensybilizację; treningi masturbacyjne; trening seksualny pary według Kratochvila; trening Guillerma. Dla osób niepełnosprawnych przeznaczone są także metody edukacyjne i psychoterapeutyczne, na przykład metoda umiejętności poznania i rozpoznania stref erogennych (tzw. mapy ciała) oraz optymalnego ich pobudzania, poradnictwo i psychoterapia w nurcie behawioralno-poznawczym, a także tzw. metody 
mechano-terapeutyczne (np. pierścienie uciskowe, aparat próżniowy). Alternatywną propozycją są kinezyterapeutyczne metody w rehabilitacji seksualnej (masaże, akupresura, hydroterapia) (Aouli 2010, s. 4-5). Jednak metody te nie zawsze spotykają się $z$ akceptacją środowiska naukowego.

\section{POTRZEBY SEKSUALNE OSÓB Z NIEPEŁNOSPRAWNOŚCIĄ INTELEKTUALNĄ}

Problemy z realizacją potrzeb seksualnych osób niepełnosprawnych intelektualnie mają odmienny charakter. Z jednej strony w dyskursie naukowym podkreśla się, że osoby te pragną realizować swoją dorosłość, uczestniczyć w życiu społecznym, podejmować role społeczne wynikające $z$ ich płci i cieszyć się swoją seksualnością. Pojawiają się także nowe możliwości realizacji tych potrzeb, dzięki odchodzeniu od instytucjonalnych i rozwijaniu pozainstytucjonalnych form wsparcia (np. mieszkań chronionych czy treningowych), które dają szansę na realizowanie się w rolach partnerskich (Kijak 2013b, s. 40). Z drugiej strony jednak na przeszkodzie tym działaniom mogą stanąć głęboko zakorzenione negatywne przekonania osób z najbliższego otoczenia niepełnosprawnych intelektualnie na temat ich seksualności i szans na realizację związanych z nią potrzeb.

Jak pokazuje wiele badań, rodzice osób z niepełnosprawnością intelektualną zwykle odbierają swoim dzieciom prawo do interesowania się własną płciowością (Kijak 2009). Izabela Fornalik (2007, s. 57) w wyniku badania opinii rodziców i opiekunów dzieci z niepełnosprawnością intelektualną wskazuje, $\dot{z}$ e $\mathrm{w}$ tej grupie $62 \%$ jest przeciwnych podjęciu współżycia przez ich podopiecznych, a wśród pozostałych dominuje niezdecydowanie. Rodzice i opiekunowie są niechętni także wobec zawierania małżeństw i posiadania dzieci przez osoby niepełnosprawne intelektualnie (Żyta 2013, s. 63). W badaniach Remigiusza Kijaka (2013b, s. 66), tylko $2 \%$ badanych rodziców deklaruje pełną akceptację seksualności swojego dziecka. Pozostali, obawiając się konsekwencji rozpoczęcia życia seksualnego, starają się hamować pobudzenie seksualne podopiecznych, próbują kojarzyć działania związane $z$ tą sferą (współżycie seksualne, masturbacja, oglądanie materiałów pornograficznych) z negatywnymi emocjami lęku i poczucia winy.

Analogiczne postawy, będące wyrazem problemów z pełnym respektowaniem prawa do seksualności osób z niepełnosprawnością intelektualną, prezentują także profesjonaliści zawodowo związani z systemem opieki, terapii, kształcenia i wychowania. Remigiusz Kijak, badając pracowników domów pomocy społecznej, warsztatów terapii zajęciowej, świeckich i katolickich szkół specjalnych, hosteli/mieszkań chronionych (treningowych), wyróżnił cztery typy postaw. Ws pierający poszukiwacze ( $36 \%$ badanych) to głównie pracownicy szkół specjalnych, opiekunowie w mieszkaniach treningowych, warsztatach terapii zajęciowej prowadzonych przez fundacje i stowarzyszenia; ich wiedza na temat seksualności osób niepełnosprawnych nie jest duża, ale są go- 
towi ją uzupełniać, by realizować działania wspierające. Po st ęp ow cy (23\%) - osoby wywodzące się z tych samych instytucji, mające odpowiednią wiedzę oraz otwarty i postępowy stosunek do kwestii związanych z seksualnością osób niepełnosprawnych, podejmujący wobec nich działania wspierające. $\mathrm{Za}$ przeczający $(22 \%)$ - są to głównie pracownicy domów pomocy społecznej, niewielką grupę stanowią nauczyciele ze szkół specjalnych; nie osiągnęli oni wystarczającego poziomu wiedzy na temat seksualności osób niepełnosprawnych i w swojej praktyce podejmują wiele niekorzystnych działań, głównie zaprzeczających i krzywdzących. Moralizatorzy (19\%) to przede wszystkim pracownicy domów pomocy społecznej oraz katolickich szkół specjalnych; ich działania zmierzały głównie do udaremniania przejawów seksualności osób niepełnosprawnych intelektualnie przez zastępowanie aktywności seksualnej innymi formami, takimi jak działania świetlicowe, modlitwa, aktywność fizyczna, twórcza, słuchanie opowiadań. Niektórzy z nich stosowali kary psychiczne (krzyk, szantaż) lub fizyczne (np. zawiązywanie rąk) (Kijak 2013b, s. 49-50).

Szczególną przestrzenią kontroli nad seksualnością osób niepełnosprawnych intelektualnie są domy pomocy społecznej. Jakub Niedbalski (2013) podczas badań etnograficznych prowadzonych w trzech domach pomocy społecznej zauważył, że personel podejmuje wiele działań, by zahamować i opanować przejawy aktywności seksualnej mieszkańców, które są postrzegane jako potencjalne źródło problemów dla pracowników. Tematy związane z seksualnością są przez nich wypierane $z$ dyskursu z podopiecznymi, traktowanymi jak dzieci, które „tymi sprawami” nie powinny się interesować. Nie oznacza to jednak, że mieszkańcy DPS-ów nie podejmują prób zachowań o charakterze seksualnym, także skierowanych do pracowników (np. „obłapianie”, natarczywy dotyk, ocieranie się itd.) (Niedbalski 2011). Jedynymi akceptowanymi aktywnościami seksualnymi (na zasadzie cichego przyzwolenia) są masturbacja i zachowania homoseksualne, które nie „grożą" niechcianą ciążą podopiecznych ${ }^{2}$. Podsumowując swoje badania Niedbalski zauważa, że personel podejmuje walkę ze zjawiskiem, którego istnieniu oficjalnie zaprzecza, próbując je wypierać ze świadomości poprzez infantylizację mieszkańców (Niedbalski 2011, s. 118).

Podobny obraz niechętnego stosunku do realizacji potrzeb seksualnych przez osoby niepełnosprawne intelektualnie wynika z badań Agnieszki Kani (2005, s. 49 i nast.) przeprowadzonych wśród uczestników konferencji naukowej (pedagogów, psychologów oraz pracowników opieki społecznej i medycznej) poświęconej temu zagadnieniu. Mimo zainteresowania tematem oraz posiadanej wiedzy jedynie $67 \%$ badanych skłonnych było uznać prawo osób $z$ nie-

${ }^{2} \mathrm{~W}$ tym kontekście warto także przywołać wyniki badań Agnieszki Kumanieckiej-Wiśniewskiej (2003, s. 124), która wyróżniła dwa podejścia personelu DPS-ów do seksualności mieszkańców - przyjęcie, że nie mają oni potrzeb seksualnych i osłabianie ich popędu seksualnego za pomocą środków psychotropowych oraz ścisła kontrola mieszkanek przez lekarza ginekologa (który zakłada antykoncepcyjne wkładki domaciczne) i pielęgniarki (przez wypełnianie kart menstruacyjnych). 
pełnosprawnością intelektualną do wyczerpującej edukacji seksualnej i seksualnej opieki zdrowotnej, a $62 \%$ prawo do równości, wolności, odrębności i prywatności seksualnej. Co dziesiąty z nich nie aprobował żadnej formy aktywności tego rodzaju.

Podsumowując badania własne, dotyczące postaw specjalistów zatrudnionych w placówkach wsparcia (warsztatach terapii zajęciowej, środowiskowych domach samopomocy, domach pomocy społecznej dla dzieci, młodzieży i dorosłych) wobec seksualności osób z umiarkowaną i znaczną niepełnosprawnością intelektualną, Monika Parchomiuk i Anna Prokopiak (2013, s. 204) zauważają, że istnieje sprzeczność $\mathrm{w}$ poglądach i działaniach respondentów. Choć $\mathrm{z}$ jednej strony uznają oni istnienie u swoich podopiecznych potrzeb seksualnych, zdolności do przyjaźni i miłości, jednocześnie nie akceptują naturalnych form ich spełnienia w postaci związków formalnych, ze współżyciem seksualnym i rodzicielstwem. Jedyną akceptowaną formą realizacji popędu pozostaje masturbacja.

Jednocześnie osoby niepełnosprawne intelektualnie jak najbardziej wykazują potrzeby i pragnienia seksualne. Jednakże jak wskazują między innymi badania Remigiusza Kijaka przeprowadzone w grupie 133 osób z niepełnosprawnością intelektualną w stopniu umiarkowanym, w ich codziennych praktykach seksualnych dominują zachowania autoerotyczne. Mniejszy niż wśród uczestników grupy kontrolnej (133 studentów pierwszego roku pedagogiki) udział w społecznych zachowaniach seksualnych wynikał z obawy przed odrzuceniem, niewiedzy, jak podjąć takie działanie, braku śmiałości w inicjowaniu takich kontaktów, wreszcie lęku przed złamaniem zakazu opiekunów (Kijak 2009 , s. 206). Pieszczoty seksualne z partnerem (w $94 \%$ przypadków była to osoba niepełnosprawna intelektualnie płci przeciwnej) podejmowało $24 \%$ badanych (Kijak 2009, s. 212). Inicjację seksualną miało za sobą $14 \%$ badanych niepełnosprawnych (wobec $84 \%$ respondentów grupy kontrolnej) (Kijak 2009, s. 220). Osoby, które wykazywały silną potrzebę kontaktu z płcią przeciwną, a w związku ze swoimi ograniczeniami nie były w stanie uczynić tego efektywnie, przejawiały zachowania ekshibicjonistyczne lub korzystały z sekstelefonów (Kijak 2009, s. 216). Warto także wspomnieć, że w badaniach przeprowadzonych przez Iwonę Boruszkowską i Grażynę Durkę (2007) wśród osób w wieku 16-21 lat z lekkim stopniem niepełnosprawności intelektualnej $90 \%$ respondentów deklarowało chęć zawarcia związku małżeńskiego, a ponad połowa tej grupy chciałaby mieć dzieci (zob. Żyta 2013, s. 63).

W podsumowaniu powyższych rozważań można zauważyć, że osoba niepełnosprawna intelektualnie ma małe szanse na odebranie edukacji seksualnej od profesjonalistów czy rodziców (tym bardziej że brak jest przemyślanej koncepcji wychowania seksualnego tej grupy osób; Kijak 2009, s. 12) i wsparcie realizacji swoich potrzeb. Wręcz odwrotnie - ich ekspresja seksualna w trakcie wychowania bywa tłumiona przez otoczenie społeczne. Taka antyedukacja seksualna może skutkować lękliwością podczas odkrywania swojej kobiecości 
lub męskości oraz brakiem wiedzy na temat pełnienia ról płciowych (Długołęcka 2007, s. 102).

\section{ALTERNATYWNE SPOSOBY ZASPOKAJANIA POTRZEB SEKSUALNYCH NIEPEENOSPRAWNYCH}

Wobec trudności z realizacją potrzeb seksualnych, jakich doświadcza przynajmniej część osób niepełnosprawnych, pojawiają się propozycje stworzenia alternatywnych dróg przeznaczonych dla tych, którzy uznają, że potrzebują specjalnego wsparcia w tym zakresie. Wśród omawianych możliwości najwięcej dyskusji wzbudzają asystentura seksualna oraz terapia z partnerem zastępczym, które w niektórych krajach znajdują zwolenników jako pomoc dla osób mających trudności w sferze seksualności. Metody te wywoływały (i wywołują) wiele kontrowersji zarówno wśród profesjonalistów zajmujących się rehabilitacją osób niepełnosprawnych, wśród samych potencjalnych odbiorców tych usług, jak i ogólnie wśród społeczeństwa ${ }^{3}$.

\section{Terapia seksualna z zastępczym partnerem, asystentura seksualna}

Idea terapii seksualnej powstała w Stanach Zjednoczonych w latach siedemdziesiątych ubiegłego wieku, a w ostatnich latach na nowo spopularyzowały ją przekazy medialne, między innymi film The Sessions, opowiadający o seksualnym przebudzeniu 38-letniego sparaliżowanego mężczyzny i jego związku $z$ seksterapeutką. Taka terapia przeznaczona jest dla osób, które między innymi ze względu na stan zdrowia (przebyte choroby, wypadki, niepełnosprawność), negatywny obraz własnego ciała, seksualne, fizyczne lub emocjonalne nadużycia i/lub urazy (np. gwałt, molestowanie) ${ }^{4}$ mają trudności $z$ realizowaniem swoich potrzeb seksualnych. Zakres osób, do których może być skierowana terapia, jest więc szeroki, choć wprowadzenie partnerów zastępczych (surrogate partners) zalecano zwłaszcza (np. Masters i Johnson) w terapii osób po urazie rdzenia kręgowego. Mieli oni pomagać osobom niepełnosprawnym w znalezieniu nowych stref erogennych oraz nowych sposobów ekspresji seksualnej (Cencora, Pasiut 2012, s. 23).

W procesie terapii kluczową rolę odgrywa trzyosobowy zespół terapeutyczny, złożony z nadzorującego terapeuty, klienta oraz zastępczego partnera seksualnego, który dla klienta $z$ dysfunkcjami pełni rolę partnera $\mathrm{w}$ treningu umiejętności społecznych (przez nawiązanie głębszego kontaktu psychicznego) i seksualnych (np. przez dotyk, masaż, pieszczoty, w niektórych przypadkach

\footnotetext{
${ }^{3}$ Niektóre wątki poruszone w tej części tekstu podjęłam także w innym opracowaniu: Ślęzak, w druku.

${ }^{4}$ Więcej informacji zob.: http://www.surrogatethe rapy.org/what-is-surrogate-partner-therapy/
} 
także pełen stosunek seksualny). Jednakże decydujący głos w sprawie działań, jakie zostaną zastosowane wobec konkretnego klienta, ma terapeuta. Czynności seksualne, których uczy zastępczy partner seksualny (jeśli terapeuta uzna je za potrzebne), mają być wtórne wobec komunikacji, edukacji i leczenia.

Zwolennikom tego podejścia bardzo zależy na podkreśleniu profesjonalnego charakteru oferowanego wsparcia. Aby zostać zastępczym partnerem zrzeszonym w International Professional Surrogates Association (IPSA), oprócz predyspozycji osobowościowych, należy ukończyć wiele kursów, uzyskać certyfikat zawodowy i podjąć współpracę z zarejestrowanym seksuologiem. Atutem jest także formalne wykształcenie $z$ zakresu psychologii, seksuologii, doradztwa, edukacji seksualnej, co ułatwia współpracę z terapeutami. Profesjonalny charakter terapii seksualnej ma podkreślać także kodeks etyczny IPSA (http:// www.surrogatetherapy.org/code-of-ethics/), który stoi na straży jakości pracy partnerów zastępczych. Zgodnie $z$ nim relacje zastępczego partnera $z$ pacjentem zawsze są tymczasowe i mogą mieć miejsce wyłącznie $\mathrm{w}$ trakcie terapii, pod nadzorem terapeuty. Obowiązkiem partnera zastępczego jest posiadanie środków antykoncepcyjnych zapobiegających ciąży i chorobom przenoszonym drogą płciową. Tożsamość pacjenta uczestniczącego w terapii powinna pozostać tajemnicą.

Pomimo wielości informacji medialnych, z powodu których można odnieść wrażenie, że tego typu usługi są powszechnie dostępne, faktycznie są one raczej niszowe. Oferowane są w niektórych stanach Stanów Zjednoczonych oraz niektórych krajach europejskich (np. Wielka Brytania, Szwajcaria, Dania, Holandia, Szwecja, Niemcy czy Włochy). W szczytowym okresie działalności w latach siedemdziesiątych IPSA skupiała w Stanach Zjednoczonych 200-300 osób, dziś jest ich około 50.

W Europie nieco większą popularnością cieszy się idea asystentury seksualnej dla osób niepełnosprawnych (intelektualnie i fizycznie). Asystenci mają za zadanie przez edukację i trening konkretnych umiejętności pomagać osobom, które z racji swoich dysfunkcji są niejako „odcieleśnione”, dla których ciało jest przede wszystkim źródłem bólu, w „odzyskaniu” ciała jako dającego im przyjemność. Usługi te oferowane są zarówno osobom, które wcześniej (np. przed wypadkiem) prowadziły aktywne życie seksualne, jak i tym, dla których interakcje $z$ asystentem są pierwszymi $w$ życiu kontaktami o zabarwieniu erotycznym. Aby pełnić swoje zadanie profesjonalnie, asystenci seksualni osób niepełnosprawnych powinni odbyć kurs obejmujący elementy psychologii, praktyczne kursy masażu i technik masturbacji oraz dostarczające wiedzy o specyfice dysfunkcji i seksualności niepełnosprawnych. W zakresie ich zadań, poza czynnościami seksualnymi, są także na przykład rozebranie, przeniesienie do łóżka, pomoc w zajęciu odpowiedniej pozycji i zastosowaniu środków antykoncepcyjnych, jeśli samodzielne wykonanie tych czynności przez klienta jest niemożliwe (Długołęcka, Fornalik 2013, s. 162). 
Kontrowersje pojawiają się zarówno w odniesieniu do zastępczych partnerów, jak i asystentów seksualnych, co w wielu krajach uniemożliwia uregulowanie tych działań, nadanie im statusu działań zawodowych, finansowanych przez fundusz ubezpieczeń społecznych lub organizacje pozarządowe (Jansen 2013, s. 78). Wielu terapeutów i pracowników społecznych (zob. Fairbairn, Rowley 2005) postrzega takie formy wspierania seksualności osób niepełnosprawnych jako rodzaj prostytucji, do której dołączono filozofię. „Terapeutyczną prostytucją" nazywają je także rodzimi autorzy (Kościelska 2013; Kijak 2013b), przedstawiając tego rodzaju usługi jako „nierozwiązaną moralnie i etycznie kwestię” (Kijak 2013b, s. 44), „wielce kontrowersyjne, szokujące i mogące bulwersować rozwiązania i pomysły" (Kijak 2009, s. 49). Podając w wątpliwość sens korzystania zarówno $z$ usług partnerów zastępczych, asystentów seksualnych, jak i z prostytucji, krytycy podważają terapeutyczne znaczenie kontaktów seksualnych $z$ kimś, $z$ kim osoba niepełnosprawna nie jest powiązana emocjonalnie. Ich zdaniem, niekoniecznie przełoży się to na korzystne zmiany w zakresie adaptacji społecznej, może wręcz obniżać samoocenę osób niepełnosprawnych i uderzać w ich godność (por. Tederko 2007). Szczególne wątpliwości pojawiają się w kontekście korzystania $z$ tej formy zaspokajania potrzeb przez osoby niepełnosprawne intelektualnie. Trudno bowiem wówczas zadecydować, kto powinien podjąć decyzję o skorzystaniu z usługi i jej zakresie; jak taka usługa byłaby definiowania $\mathrm{w}$ prawie polskim i czy w przypadku osoby $\mathrm{z}$ głębszą postacią niepełnoprawności zarówno asystenta, jak i jej rodziców czy opiekunów nie postawiłoby to $\mathrm{w}$ konflikcie $\mathrm{z}$ wymiarem sprawiedliwości; istnieją wreszcie obawy, jakie konsekwencje emocjonalne miałaby taka relacja dla osób niepełnosprawnych intelektualnie, które nie rozumiałyby jej komercyjnego charakteru (Długołęcka, Fornalik 2013, s. 184-187). Także osoby niepełnosprawne, które są propagatorami idei asystentów seksualnych (np. Marcel Nuss, mężczyzna z całkowitym porażeniem czterokończynowym, założyciel organizacji Coordination Handicap et Autonomie czy Aiha Zemp z organizacji Fachstelle „Behinderung und Sexualität”, działająca na rzecz dostępu osób niepełnosprawnych do refundowanej pomocy asystentów seksualnych), są zdania, że do tego rodzaju wsparcia kwalifikują się jedynie te osoby niepełnosprawne, które nie mają innej możliwości realizowania swoich potrzeb, także na drodze autoerotyki (Długołęcka, Fornalik 2013, s. 168). Niektórzy badacze zwracają jednak uwagę, że metody te mają w sobie pewien potencjał (i z pewnością nie jest to „prostytucja w przebraniu”), choć trudno jest ocenić, czy jest to brakujące ogniwo rehabilitacji seksualnej (Długołęcka, Fornalik 2013, s. 190).

W Polsce pytanie o akceptację usług asystenta seksualnego zadano w badaniu realizowanym na niewielkiej próbie osób po urazie rdzenia kręgowego. Większość z 30 badanych była pozytywnie nastawiona do idei wprowadzenia asystenta seksualnego dla osób, które zgłosiłyby taką potrzebę, a 1/3 respondentów rozważałaby skorzystanie $z$ takich usług (zob. Długołęcka, For- 
nalik 2013, s. 168). Nieco inaczej kształtują się poglądy profesjonalistów, zbadane przez Małgorzatę Kościelską podczas dwóch konferencji w Krakowie i Bydgoszczy, dotyczących seksualności osób niepełnosprawnych. Autorka pytała uczestników o opinie na temat pięciu kwestii związanych z seksualnością osób niepełnosprawnych, w tym propozycji „otwarcia rynku płatnych usług seksualnych dla osób z niepełnosprawnościami, wzorem niektórych krajów, i kwestii ich finansowania: z urzędu lub zasobów własnych" (Kościelska 2013, s. 35). Absolutnie przeciw takiemu rozwiązaniu było $26 \%$ respondentów z Bydgoszczy $(\mathrm{N}=250)$ i $30 \%$ z Krakowa $(\mathrm{N}=65)$. Pozostali wyrazili poparcie dla tej idei, $z$ tym że wskazywali odmienne źródła jej finansowania. $34 \%$ respondentów z Krakowa wsparło pomysł refundacji tych usług, a 59\% z Bydgoszczy uznało, że płacić za nie powinni sami zainteresowani (Kościelska 2013, s. 43). Nieco mniejsze poparcie dla idei korzystania z usług seksualnych przez osoby niepełnosprawne można odnaleźć wśród ogółu społeczeństwa. W badaniach Zbigniewa Izdebskiego na reprezentatywnej próbie Polaków wprowadzenie tego rodzaju usług (opłaconych przez „kogoś z rodziny”) poparło $46 \%$ respondentów w odniesieniu do osób niepełnosprawnych ruchowo i $45 \% \mathrm{w}$ przypadku osób niepełnosprawnych intelektualnie. Jednakże jeśli $\mathrm{w}$ pytaniu dodano warunek, by usługi te były zapewniane $\mathrm{w}$ ramach opieki społecznej, poparcie tej idei zmalało ( $27 \% \mathrm{w}$ odniesieniu do niepełnosprawnych ruchowo i $24 \%$ do niepełnosprawnych intelektualnie). Warto także zauważyć, że przy obu pytaniach znaczna część respondentów wybrała odpowiedź „trudno powiedzieć” (odpowiednio 30\% i 23\%-24\%) (Izdebski 2005, s. 44).

\section{Prostytucja}

Prostytucja jest jedną z propozycji dla osób niepełnosprawnych (zarówno mężczyzn, jak i kobiet), które nie mogą realizować swoich potrzeb seksualnych $z$ własnymi partnerami, a także tych, które choć mogłyby znaleźć partnerów, wybierają komercyjne usługi seksualne. W naszym kraju jest to jedyna forma komercyjnych usług seksualnych dostępna dla osób niepełnosprawnych, ale nie jest ona $\mathrm{w}$ żaden sposób dostosowana do ich potrzeb i możliwości.

Trudno określić, jaki wśród klientów prostytutek jest udział osób niepełnosprawnych, ponieważ $\mathrm{w}$ zasadzie nie ma odpowiednich danych. Jednak badania nad prostytucją przeprowadzone w 2002 roku przez zespół Zbigniewa Izdebskiego, na próbie 400 kobiet świadczących usługi seksualne na ulicy i w agencjach w wybranych miastach Polski, wskazuja, że osoby niepełnosprawne występują $\mathrm{w}$ roli klientów. Według deklaracji badanych kobiet, $20 \% \mathrm{z}$ nich świadczyło usługi „osobom niepełnosprawnym, inwalidom” (Izdebski, Bartosik, Kaliwoda 2002, s. 61). Ze względu na narzędzie badawcze (kwestionariusz wywiadu) oraz ilościowy charakter badań nie można określić, jak respondentki 
rozumiały „niepełnosprawność” czy „inwalidztwo”. Trudno więc stwierdzić, jakiego rodzaju dysfunkcje charakteryzowały ich klientów.

W literaturze przedmiotu można spotkać zróżnicowane postawy wobec takiego sposobu zaspokajania potrzeb seksualnych przez osoby niepełnosprawne. Często są one negatywne lub warunkowo pozytywne ${ }^{5}$. Jednocześnie niektórzy autorzy przedstawiają znane sobie przypadki mężczyzn (wyłącznie), którzy $\mathrm{z}$ niego korzystali, a nawet zwracali się o pomoc w zorganizowaniu takiego spotkania do personelu opiekuńczego (Fairbairn, Rowley 2005). Andrzej Jaczewski (2013, s. 26) opisuje przypadek jednego ze swoich pacjentów, młodego mężczyzny, kwadraplegika (porażenie mózgowe, brak możliwości używania dolnych i górnych kończyn), który ze względu na bardzo silny popęd seksualny oraz trudności w znalezieniu partnerki seksualnej korzystał $\mathrm{z}$ usług prostytutek. Ponieważ jednak nie mógł sam zorganizować takiego spotkania, pośredniczył w tym kolega. Taki sposób realizacji potrzeb nie przynosił mu satysfakcji, czuł się upokorzony, kolega zaś nie był zbyt chętny do pomocy. Rozwiązanie to ma więc bariery związane $z$ możliwością zaaranżowania spotkania, fizyczną dostępnością miejsca spotkania, poniesieniem kosztów i często wymaga pomocy osób trzecich ${ }^{6}$ (zwykle rodziców czy przyjaciół), a więc także wtajemniczenia ich w swoje plany. Nierzadko jest to sytuacja krępująca i trudna (także ze względów moralnych) dla obu stron (Izdebski 2005, s. 29-30; Fairbairn, Rowley 2005).

Poza tym zwraca się uwagę na pewne zagrożenia dla osób niepełnosprawnych korzystających z tej formy usług seksualnych. Wśród porad pracownic seksualnych dla osób niepełnosprawnych, które rozważają skorzystanie z prostytucji, zamieszczonych w książce Petnosprawni! Uniwersalny przewodnik po seksie dla tych, którzy żyja z niepetnosprawnościa, chronicznym bólem i choroba (Kaufman, Silverberg, Odette 2013), jedna z najważniejszych dotyczy tego, by nie korzystać z usług agencji i przypadkowych osób, ponieważ niepełnosprawny klient bywa postrzegany jako łatwa ofiara, którą na przykład można okraść. Aby spotkanie było satysfakcjonujące, warto udać się do osoby poleconej przez innego klienta oraz upewnić się, czy jest ona przygotowana do tego, by poradzić sobie z problemami seksualnymi związanymi z różnymi rodzajami niepełnosprawności. Kluczową kwestią wydaje się właściwy dobór partnera/ki i miejsca takiego spotkania. Wyniki badań dotyczących agencji towarzyskich jako przestrzeni realizacji usług seksualnych pozwalają zauważyć, że nie jest to zadanie proste (Ślęzak, w druku).

${ }^{5}$ Do tej grupy można zaliczyć wypowiedź: „Jestem przeciw kupczeniu seksem i miłością, ale zdaję sobie sprawę z tego, że jeżeli istnieje społeczne zezwolenie na płatną miłość między osobami pełnosprawnymi, to nie widzę powodów, dla których niepełnosprawni mieliby być z tego przyzwolenia wyłączeni" (Kościelska 2013, s. 45).

${ }^{6}$ Między innymi ten wątek obecny jest w filmach: Hasta la Vista!, Sztuka latania, Jak to jest, w których jest poruszana kwestia potrzeb seksualnych osób niepełnosprawnych. 


\section{AGENCJE TOWARZYSKIE JAKO PRZESTRZEŃ REALIZACJI POTRZEB SEKSUALNYCH PRZEZ OSOBY NIEPEŁNOSPRAWNE}

Poniższe wnioski pochodzą z badań dotyczących sytuacji pracy kobiet świadczących usługi seksualne w agencjach towarzyskich (Ślęzak 2016). Ich podstawą jest 56 wywiadów swobodnych przeprowadzonych z pracownicami czterech łódzkich agencji. Każda z rozmówczyń miała doświadczenia spotkań $z$ niepełnosprawnymi klientami. Zebrane dane zostały poddane analizie przy użyciu procedur analitycznych metodologii teorii ugruntowanej (zob. Konecki 2000; Glaser, Strauss 2009). Poniżej zaprezentuję wybrane subkategorie związane $z$ jedną $z$ wygenerowanych kategorii - kategorią tru dne go klienta.

Wyniki badań wskazują, że agencje towarzyskie nie są dostępne dla każdej osoby niepełnosprawnej. Wśród klientów badanych agencji byli jedynie mężczyźni, kobiety (niepełnosprawne i pełnosprawne) nie korzystały $z$ tej formy komercyjnych usług seksualnych. Ze względu na rodzaj niepełnosprawności klientami byli wyłącznie niepełnosprawni ruchowo w stopniu, który nie uniemożliwiał im przybycia do lokalu oraz nie zakłócał w znaczący sposób komunikacji. Nie bez znaczenia jest także fakt, że były to osoby, które mogły sobie pozwolić na opłacenie usługi.

Niezależnie od tego niepełnosprawni mężczyźni byli postrzegani przez badane pracownice jako kłopotliwi i trudni klienci, czyli tacy, z którymi spotkanie „na pokoju” odbiegało od typowych, standardowych scenariuszy i wymagało wzmożonego wysiłku interpretacyjnego i interakcyjnego. Wśród badanych kobiet tylko nieliczne były gotowe podjąć to wyzwanie. $Z$ tego względu dominującymi wzorami przebiegu interakcji między pracownicami agencji a ich potencjalnymi klientami — niepełnosprawnymi mężczyznami — była odmowa spotkania lub niechętne jego przeprowadzenie, co wiązało się z nikłym zaangażowaniem pracownicy $\mathrm{w}$ interakcję seksualną oraz nieprzyjemnym komentowaniem jej przebiegu.

Deklarowane przez pracownice powody odmowy realizacji spotkania można połączyć w trzy bloki. Po pierwsze, odnoszą się one do estetyki niepełnosprawnego ciała, która była dla nich nie do zaakceptowania. Ze względu na to, że spotkanie „na pokoju” rozgrywa się wokół ciała, deformacje, które oddalają je od „typowego”, przyjętego w naszej kulturze wzorca, mogą być powodem odczuwanego przez pracownice zakłopotania, a w skrajnych przypadkach obrzydzenia. Tym bardziej że badane kobiety często utożsamiały ciało ułomne $z$ ciałem brudnym, spodziewając się dyskomfortu, także pod względem higieny osoby niepełnosprawnej:

No przychodza niepetnosprawni, przychodza, ale nie obstugujemy. Ja nie mogę iść z takim. Jak nie ma nogi czy coś. Dla mnie to nie do zrobienia jest. Jakoś mnie odrzuca. No nie mogę. A dziewczyny mówity, że to iz higieną czasem jest u nich problem [kobieta, 22 lata, 3 lata pracy $\mathrm{w}$ agencji]. 
Po drugie, niepełnosprawni klienci postrzegani byli jako aseksualni, nie tylko jako nieposiadający potrzeb seksualnych, ale i jako trwale wykluczeni $z$ tej sfery życia. W tym kontekście pracownice nierzadko ze zdziwieniem komentowały wizytę niepełnosprawnego klienta w agencji (Po co o tu przyszedt? On serio chce skorzystać? [kobieta, 30 lat, 1,5 roku pracy w agencji]). Ich wyobrażenie o osobie niepełnosprawnej nie obejmowało zainteresowania tego rodzaju „uciechami” życia. Osoba doświadczona przez los powinna - ich zdaniem raczej koncentrować się na codziennych zmaganiach z barierami i ograniczeniami, na „poważnych sprawach”, a nie odwiedzać agencję.

Po trzecie, w konsekwencji przekonania o aseksualnym charakterze osób niepełnosprawnych pracownice nie wiedziały (i często nie potrafiły sobie wyobrazić), jak mogłoby przebiegać spotkanie seksualne:

I co on sobie wyobraża, że będę $z$ nim robić? Jak ja niby miałabym $z$ nim seks uprawiać? Przecież to nawet nie wiadomo jak zaczać [kobieta, 23 lata, 4 lata pracy w agencji].

Obawa o przebieg spotkania ma podłoże w kilku czynnikach. Rozmówczynie zwykle nie miały wcześniejszych doświadczeń interakcji z osobami niepełnosprawnymi ${ }^{7}$ (zarówno w kontekście agencji, jak i poza nim), obawiały się więc ich i wolały uniknąć. Ponieważ współpracownice także zwykle nie wypracowały schematów przebiegu spotkania z klientem niepełnosprawnym, nie mogły w procesie socjalizacji zawodowej przekazać swoich doświadczeń nowicjuszkom. W tej sytuacji akceptowanym i przekazywanym w grupie współpracownic wzorem działania było wycofanie się z interakcji.

Rozmówczynie nie dysponowały także wiedzą na temat wpływu różnego rodzaju dysfunkcji klientów na możliwość zrealizowania stosunku seksualnego. Postrzegając jedynie powierzchowność mężczyzny, nie potrafiły ocenić, w jakim stopniu niepełnosprawność jest poważna, jak może interweniować w przebieg aktu seksualnego i w jaki sposób trzeba byłoby go przeprowadzić. Podobnie jak większość naszego społeczeństwa nigdy nie miały okazji zapoznać się z naukowymi ustaleniami czy choćby podstawową wiedzą seksualną w tym zakresie. Niewiedzę i obawy nierzadko maskowały prowokacyjnym, niedelikatnym zachowaniem, co tym bardziej nie dawało szansy na zbudowanie atmosfery zaufania czy intymności, sprzyjającej wspólnemu poszukiwaniu sposobów zaspokojenia seksualnego konkretnego klienta w jego specyficznej sytuacji. Poza tym, jak (słusznie) podejrzewały rozmówczynie, spotkanie z niepełnosprawnym mężczyzną wymagałoby od nich więcej zaangażowania. Dla wielu $z$ nich był to niepotrzebny wysiłek, gdyż taką samą kwotę mogły zarobić podczas spotkania $z$ typowym klientem agencji, $z$ którym schematy postępowania były prostsze i wielokrotnie przećwiczone.

7 W tym miejscu warto przywołać wyniki badań Antoniny Ostrowskiej (1997, s. 86), z których wynika, że blisko $60 \%$ badanych unika kontaktów z niepełnosprawnymi, ponieważ nie wiedzą lub nie są pewni, jak się zachować w ich obecności. 
Źródłem obaw związanych z interakcją z niepełnosprawnym klientem były także antycypowane problemy techniczne podczas interakcji. Wiązały się one $z$ trudnościami ze skorzystaniem przez klienta $z$ obowiązkowego przed spotkaniem seksualnym prysznica, wejściem na łóżko itd. Pracownice nie widziały siebie $w$ roli osoby pomagającej $w$ wykonaniu tych czynności, $w$ agencjach nie było także nikogo innego, kto mógłby takiej pomocy udzielić. Należy także zaznaczyć, że żaden z badanych lokali nie był architektonicznie przystosowany do potrzeb niepełnosprawnych. Wysokie, strome schody, brak wind i podjazdów, wąskie drzwi, ciasne i/lub niedostosowane łazienki, pokoje (brak drą̇̇ów, poręczy itd.) faktycznie czyniły przestrzeń agencji niedostępną dla klientów, którzy mają problemy z poruszaniem się.

Wszystko to sprawiało, że zdecydowana większość badanych kobiet nie godziła się na spotkania z niepełnosprawnymi. Tym bardziej że niepełnosprawność fizyczna jest atrybutem, który czyni z danego mężczyzny osobę zdyskredytowaną (Goffman 2005, s. 34). Ponieważ ten rodzaj piętna charakteryzuje potencjalnie duża natarczywość i percepcyjne „zagęszczenie” podczas interakcji (Goffman 2005, s. 85-86), ukrycie przed pracownicą agencji czy zamaskowanie dyskredytujących atrybutów często jest niemożliwe. Są one widoczne na pierwszy rzut oka lub najpóźniej w momencie rozpoczęcia interakcji seksualnej, co modyfikuje działania pracownicy.

Niektóre rozmówczynie $\mathrm{w}$ trakcie swojej pracy $\mathrm{w}$ agencji zdecydowały się na odbycie spotkania z niepełnosprawnym klientem. Jednak zazwyczaj kończyto się ono przed upływem opłaconego czasu oraz przebiegało w niezbyt przyjaznej atmosferze. W dużej mierze dlatego, że pracownice szybko się zniechęcały i dążyły do przerwania interakcji, która w związku z trudnościami seksualnymi partnera wymagała od nich, ich zdaniem, zbyt wiele pracy i modyfikowania swojego zachowania. Choć takie wyjaśnienie nie było formułowane wprost, można założyć, że jedną z przyczyn tych reakcji mogła być faktyczna nieumiejętność poradzenia sobie w sytuacji, gdy zaspokojenie potrzeb seksualnych partnera wymagało niestandardowych działań (przyjmowania specjalnych pozycji czy poszukiwania sfer erogennych). Rozmówczynie, by przerwać interakcję i pozbyć się klienta, zwykle wprost i niekoniecznie w delikatnych słowach wyrażały swoje niezadowolenie z przebiegu spotkania, całkowicie obwiniając za niepowodzenie mężczyznę. Zawstydzając czy upokarzając klienta nie tylko próbowały obronić swoją profesjonalną tożsamość (jako skutecznej pracownicy seksualnej, potrafiącej poradzić sobie $z$ każdym klientem), ale również starały się zniechęcić go do ponownej wizyty, co uwalniało je od konieczności interakcji w przyszłości.

Nie powinno więc dziwić, że niepełnosprawni mężczyźni nie byli częstymi gośćmi $w$ badanych agencjach, nie byli w nich także oczekiwani. Żadna $z$ badanych kobiet, mimo nierzadko długiego stażu w prostytucji, nie wyspecjalizowała się w kontaktach z osobami niepełnosprawnymi, które przecież mogłyby stanowić szerokie grono odbiorców ich usług. Każdorazowe przyjście takiego 
klienta było żywo i długo komentowane w gronie pracownic i stanowiło swego rodzaju sensację bądź ciekawostkę.

Podsumowując można zauważyć, że ze względu na konieczność przyjazdu do lokalu, uiszczenia opłat i realizowania określonego wzoru interakcji, który obowiązuje podczas spotkania $z$ pracownicą agencji towarzyskiej, nie jest to sposób zaspokojenia potrzeb seksualnych dostępny dla wszystkich, a z uwagi na zachowanie pracownic seksualnych nawet te osoby, które mogą z niego skorzystać, niekoniecznie będą usatysfakcjonowane.

\section{PODSUMOWANIE}

Analizując wyniki badań dotyczących realizacji potrzeb seksualnych przez osoby niepełnosprawne można zauważyć, że istnieją dwa poziomy postrzegania tego zjawiska. Z jednej strony naukowcy, profesjonaliści i opinia publiczna akceptują zarówno istnienie, jak i chęć realizacji takich potrzeb (choć wobec osób niepełnosprawnych intelektualnie postawy są bardziej ambiwalentne). Z drugiej strony istnieje milczące założenie, że osoby te ze swoją seksualnością powinny poradzić sobie same w społecznie akceptowany sposób. W literaturze przedmiotu, dowartościowując sferę potrzeb seksualnych osób niepełnosprawnych, zakłada się zatem, że powinny być one realizowane $\mathrm{w}$ intymnych bliskich związkach, opartych na miłości. Wiele osób niepełnosprawnych realizuje ten wzór, tworząc (z osobami pełno- lub niepełnosprawnymi) udane związki partnerskie, małżeństwa, rodziny. Jednakże osoby, które nie mogą lub nie chcą temu sprostać, zderzają się ze społecznym tabu. Trudno jest im otrzymać od specjalistów rzetelne i wyczerpujące informacje na temat terapii seksualnej8 czy innych możliwych sposobów rozwiązania problemów w tej sferze. Wynika to także z niewystarczającego przygotowania wielu z nich (zwłaszcza pielęgniarek, pracowników socjalnych) i braku wiedzy o potrzebach seksualnych osób niepełnosprawnych, co utrudnia reagowanie w sposób naturalny i ze zrozumieniem na ich potrzeby (Ostrowska 2007, s. 21). Popularne modele adaptacji, rehabilitacji czy integracji nie zawierają (lub zawierają zbyt mało) propozycji działań, które mogłyby pomóc $w$ realizacji tych najbardziej osobistych i intymnych potrzeb (Ostrowska 2007, s. 14). Kulturowo usankcjonowane zepchnięcie na margines potrzeb seksualnych osób niepełnosprawnych powoduje, że proces rehabilitacji w niewielkim stopniu dotyczy sfery seksualnej. Brak jest systemu zindywidualizowanego poradnictwa czy terapii dla osób niepełnosprawnych i ich bliskich. Osoby te, ze swoimi fantazjami i potrzebami, a także frustracjami i trudnościami, zbyt często pozostają same, nierozumiane przez partnerów czy członków rodzin oraz pozbawione wsparcia profesjonalistów,

${ }^{8}$ Z nielicznymi wyjątkami, na przykład Fundacja Aktywnej Rehabilitacji podczas obozów aktywnej rehabilitacji organizuje spotkania informacyjne i poradnictwo w zakresie rehabilitacji seksualnej, które mogłyby być wstępem do właściwej terapii (Cencora, Pasiut 2012, s. 23). 
którzy mogliby ułatwić odnalezienie indywidualnego sposobu radzenia sobie w tej sytuacji. Uznawane za alternatywne (choć społecznie nieakceptowane) komercyjne usługi seksualne nie rozwiązują tej kwestii, gdyż usługi wyspecjalizowanych pracowników seksualnych (asystentów seksualnych, terapeutów), posiadających wiedzę na temat niepełnosprawności i preferujących kontakty $z$ tą kategorią klientów, w naszym kraju są niedostępne, a „zwykłe” usługi w agencjach towarzyskich raczej nie spełnią oczekiwań osób niepełnosprawnych ze względu na niechęć i brak odpowiedniego przygotowania pracujących w nich kobiet. Jak się wydaje, osoby najbardziej potrzebujące wsparcia (edukacji, terapii seksualnej, być może również usług seksualnych) przy obecnych rozwiązaniach go nie otrzymują.

\section{BIBLIOGRAFIA}

Adamczyk Jakub G., Kocyk Sylwia, Boguszewski Dariusz, 2012, Oczekiwania osób niepetnosprawnych i fizjoterapeutów wobec rehabilitacji seksualnej, „Seksuologia Polska”, t. 10, nr 1, s. 21-27.

Aouil Bassam, 2010, Kinezyterapeutyczne metody rehabilitacji seksualnej osób niepetnosprawnych, „Przegląd Terapeutyczny", nr 8, s. 1-13.

Boruszkowska Iwona, Durka Grażyna, 2007, Małżeństwo i opinia w opinii uczniów z lekka niepetnosprawnościa intelektualna, w: Teresa Żółkowska (red.), Pedagogika specjalna — koncepcje i rzeczywistość. Konteksty pedagogiki specjalnej, t. 2, Wydawnictwo Print Group Daniel Krzanowski, Szczecin.

Cencora Monika, Pasiut Szymon, 2012, Rehabilitacja seksualna po urazie rdzenia kręowego, „Fizjoterapia", t. 20, nr 2, s. 12-31.

Długołęcka Alicja, 2007, Seksualność osób niepetnosprawnych fizycznie - zarys problemów, w: Antonina Ostrowska (red.), O seksualności osób niepetnosprawnych, Garmond, Warszawa.

Długołęcka Alicja, Fornalik Izabela, 2013, Ustugi seksualne w procesie rehabilitacji seksualnej osób z niepetnosprawnością ruchowa i intelektualna, w: Robert Kowalczyk, Małgorzata Leśniak (red.), Prostytucja. Studium zjawiska, Oficyna Wydawnicza AFM, Kraków.

Fairbairn Gavin, Rowley Denis, 2005, Etyczne aspekty seksualności osób z niepetnosprawnościa intelektualna, w: Joanna Głodkowska, Andrzej Giryński (red.), Seksualność osób z niepetnosprawnościa intelektualna - uwalnianie od schematów i uprzedzeń, APS im. Marii Grzegorzewskiej, Warszawa.

Filc Redlińska Izabela, 2010, Miłość sprawna inaczej, „Rzeczpospolita” (http://www.rp.pl/artykul/ 566746-Seks-niepelnosprawnych.html [06.06.2015]).

Fornalik Izabela, 2007, Miłość, seks i prokreacja jako wartości w dorostym życiu osoby z głębsza niepetnosprawnością intelektualna, w: Antonina Ostrowska (red.), O seksualności osób niepetnosprawnych, Garmond, Warszawa.

Glaser Barney G., Strauss Anselm L., 2009, Odkrywanie teorii ugruntowanej. Strategie badania jakościowego, tłum. Marek Gorzko, Nomos, Kraków.

Goffman Erving, 2005, Piętno. Rozważania o zranionej tożsamości, tłum. Aleksandra Dzierżyńska, Joanna Tokarska-Bakir, Gdańskie Wydawnictwo Psychologiczne, Gdańsk.

Iwasiów Inga, 2002, Ciato niechciane. Pogranicza identyfikacji seksualnej jako problem literatury i krytyki literackiej, w: Hanna Gosk (red.), Codzienne, przedmiotowe, cielesne. Jezzyki nowej wrażliwości w literaturze polskiej XX w., Świat Literacki, Izabelin.

Izdebski Zbigniew, 2005, Postawy Polaków wobec seksualności osób niepetnosprawnych ruchowo i intelektualnie, w: Joanna Głodkowska, Andrzej Giryński (red.), Seksualność osób z niepetnosprawnościa intelektualna — uwalnianie od schematów i uprzedzeń, APS im. Marii Grzegorzewskiej, Warszawa. 
Izdebski Zbigniew, Bartosik Grzegorz, Kaliwoda Anna, 2002, Zachowanie seksualne $i$ wiedza na temat HIV/AIDS w grupie kobiet świadczacych ustugi seksualne. Raport TNS OBOP (http://www.aids.gov. pl/badania_spoleczne/228 [29.09.2014]).

Jaczewski Andrzej, 2013, Seksualność osób niepetnosprawnych — współczesne pola dyskusji i polemiki badawczej, w: Remigiusz J. Kijak (red.), Seksualność - niepetnosprawność - rzeczywistość. Współczesne konteksty badawcze w problematyce seksualności człowieka z niepetnosprawnościq, Instytut Rozwoju Służb Społecznych, Warszawa.

Jansen Nina, 2013, Życie niepetnosprawnych w Holandii, „Czas Kultury”, nr 1.

Kania Agnieszka, 2005, Postawy studentów APS i uczestników konferencji wobec seksualności osób z niepetnosprawnościa intelektualna w: Joanna Głodkowska, Andrzej Giryński (red.), Seksualność osób z niepetnosprawnościa intelektualna - uwalnianie od schematów i uprzedzeń, APS im. Marii Grzegorzewskiej, Warszawa.

Karwacka Monika, 2006, Stereotypy w myśleniu o seksualności osób z niepetnosprawnościa intelektualna, w: Władysław Dykcik, Andrzej Twardowski (red.), Poznańska pedagogika specjalna. Tradycje osiagnięcia - perspektywy rozwoju, Wydawnictwo Naukowe UAM, Poznań.

Kaufman Miriam, Silverberg Cory, Odette Fran, 2013, Petnosprawni! Uniwersalny przewodnik po seksie dla tych, którzy żyją z niepetnosprawnościa, chronicznym bólem i choroba, tłum. Joanna Bold, Wydawnictwo Czarna Owca, Warszawa.

Kijak Remigiusz J., 2009, Seks i niepetnosprawność. Doświadczenia seksualne osób z niepetnosprawnościa intelektualna, Impuls, Kraków.

Kijak Remigiusz J., 2013a, Wprowadzenie w problematykę seksualności osób z niepetnosprawnościq — między teoria a empiria, w: Remigiusz J. Kijak (red.), Seksualność — niepetnosprawność - rzeczywistość. Wspótczesne konteksty badawcze $w$ problematyce seksualności człowieka z niepetnosprawnościa, Instytut Rozwoju Służb Społecznych, Warszawa.

Kijak Remigiusz J., 2013b, Instytucjonalne i systemowe uwarunkowania przemian wokót problematyki seksualności osób z głębsza niepetnosprawnościa intelektualna od instytucji totalnej w kierunku supported living, „Niepełnosprawność. Dyskursy Pedagogiki Specjalnej”, nr 9, s. 36-56.

Konecki Krzysztof, 2000, Studia z metodologii badań jakościowych. Teoria ugruntowana, Wydawnictwo Naukowe PWN, Warszawa.

Kościelska Małgorzata, 2004, Niechciana seksualność. O ludzkich potrzebach osób niepetnosprawnych intelektualnie, Jacek Santorski \& Co, Warszawa.

Kościelska Małgorzata, 2013, W którym miejscu jesteśmy i co chcemy osiagnać w rozważaniach $i$ działaniach na rzecz osób niepetnosprawnych $w$ aspekcie ich seksualności, w: Remigiusz J. Kijak (red.), Seksualność - niepetnosprawność - rzeczywistość. Współczesne konteksty badawcze w problematyce seksualności człowieka z niepetnosprawnościa, Instytut Rozwoju Służb Społecznych, Warszawa.

Kumaniecka-Wiśniewska Agnieszka, 2003, Tożsamość kobiet upośledzonych umystowo a środowisko spoteczne, w: Anders Gustavsson, Jan Tøssebro, Elżbieta Zakrzewska-Manterys (red.), Niepetnosprawność intelektualna a style życia, Wydawnictwo IFiS PAN, Warszawa.

Lew-Starowicz Zbigniew, 1999, Życie intymne osób niepetnosprawnych, Saverus, Warszawa.

Lew-Starowicz Zbigniew, Długołęcka Alicja, 2006, Edukacja seksualna, Świat Książki, Warszawa.

Mironiuk-Netreba Alicja, 2013, Seksualność osób z niepetnosprawnością ruchowa w sztuce filmowej czyli kilka refleksji o edukacyjnym potencjale popkultury, „Studia Edukacyjne”, nr 29, s. 285-304.

Niedbalski Jakub, 2011, (Nie-)zdrowa miłość - seksualność niepetnosprawnych umystowo mieszkańców domu pomocy społecznej, w: Eliza Litak, Renata Furman, Hubert Bożek (red.), Pejzaże tożsamości. Teoria $i$ empiria $w$ perspektywie interdyscyplinarnej, Wydawnictwo Uniwersytetu Jagiellońskiego, Kraków.

Niedbalski Jakub, 2013, Żyć i pracować $w$ domu pomocy społecznej. Socjologiczne studium interakcji personelu $z$ upośledzonymi umysłowo podopiecznymi, Wydawnictwo Uniwersytetu Łódzkiego, Łódź. 
Ostrowska Antonina, 1997, Postawy społeczeństwa polskiego w stosunku do osób niepetnosprawnych, w: Anders Gustavsson, Elżbieta Zakrzewska-Manterys (red.), Upośledzenie w spotecznym zwierciadle, Wydawnictwo Żak, Warszawa.

Ostrowska Antonina, 2000, Społeczeństwo wobec niepetnosprawnych, w: Joanna Sikorska (red.), Spoteczne problemy osób niepetnosprawnych, Wydawnictwo IFiS PAN, Warszawa.

Ostrowska Antonina, 2007, Seksualność osób niepetnosprawnych, w: Antonina Ostrowska (red.), O seksualności osób niepetnosprawnych, Garmond, Warszawa.

Parchomiuk Monika, Prokopiak Anna, 2013, Profesjonaliści wobec seksualności osób z niepetnosprawnościa intelektualna, w: Remigiusz J. Kijak (red.), Seksualność - niepetnosprawność - rzeczywistość. Współczesne konteksty badawcze w problematyce seksualności człowieka z niepetnosprawnościa, Instytut Rozwoju Służb Społecznych, Warszawa.

Pilecka Władysława, 2004, Wychowanie seksualne w systemowej rehabilitacji dziecka niepetnosprawnego, w: Bassam Aouil, Małgorzata Kościelska (red.), Człowiek niepetnosprawny. Rodzina i praca, Wydawnictwo Akademii Bydgoskiej, Bydgoszcz.

Radomski Dariusz, 2004, Ocena życia seksualnego osób z niepetnosprawnością fizyczna, w: Bassam Aouil, Małgorzata Kościelska (red.), Człowiek niepetnosprawny. Rodzina i praca, Wydawnictwo Akademii Bydgoskiej, Bydgoszcz.

Ślęzak Izabela, 2016, Praca kobiet świadczacych ustugi seksualne w agencjach towarzyskich, Wydawnictwo Uniwersytetu Łódzkiego, Łódź.

Ślęzak Izabela, w druku, Mężczyźni z niepetnosprawnościa fizyczna jako klienci agencji towarzyskich. Perspektywa pracownic seksualnych, InterAlia.

Tederko Piotr, 2007, Zaburzenia seksualne u osób po urazie rdzenia kręgowego, w: Antonina Ostrowska (red.), O seksualności osób niepetnosprawnych, Garmond, Warszawa.

Żuraw Hanna, 2013, Społeczno-kulturowy kontekst analiz nad seksualnościa osób niepetnosprawnych, w: Remigiusz J. Kijak (red.), Seksualność - niepetnosprawność - rzeczywistość. Wspótczesne konteksty badawcze $w$ problematyce seksualności człowieka z niepetnosprawnością, Instytut Rozwoju Służb Społecznych, Warszawa.

Żyta Agnieszka, 2013, Matżenstwa i rodzicielstwo osób z niepetnosprawnościa intelektualna — wyzwania wspótczesności, „Edukacja Dorosłych”, nr 2(69), s. 59-71.

\section{FULFILLMENT OF THE SEXUAL NEEDS OF DISABLED PERSONS: REALITY, PERSPECTIVES, AND CONTROVERSIES}

\section{Summary}

The aim of this article is to examine how the sexuality of disabled persons is perceived by persons in their immediate surroundings (parents, caretakers, health professionals). The latter's understanding of the question is one of the factors affecting how disabled persons define their needs and what possibility they will have of fulfilling them. On the basis of the literature on the subject, the author presents the findings of research concerning the satisfaction of sexual needs by persons with a physical or mental disability. She also indicates various 'alternative' methods of fulfilling these needs, such as sexual assistance, sexual therapy with a substitute partner (on the basis of the literature on the subject), and prostitution (on the basis of her own research). Consideration of the scientific and popular perspectives and the socially accepted or unaccepted manners by which disabled persons can satisfy their sexual needs makes it possible to determine to what degree these persons' right to fulfill their sexual needs is realized in practice. 
Key words / słowa kluczowe

physical disability / niepełnosprawność ruchowa; intellectual disability / niepełnosprawność intelektualna; sexual needs / potrzeby seksualne; prostitution / prostytucja; sexual assistance / asystent seksualny 